\title{
Calcium-activated potassium channels in ischemia reperfusion: a brief update
}

\author{
Jean-Yves Tano ${ }^{1,2 *}$ and Maik Gollasch ${ }^{1,2 *}$ \\ ${ }^{1}$ Experimental and Clinical Research Center, Charité University Medicine - Max Delbrück Center (MDC) for Molecular Medicine, Berlin, Germany \\ ${ }^{2}$ Nephrology/Intensive Care Section, Charité University Medicine, Berlin, Germany
}

\author{
Edited by: \\ Alex M. Dopico, The University of \\ Tennessee Health Science Center, \\ USA \\ Reviewed by: \\ Anthony Lewis, University of \\ Portsmouth, UK \\ Geoff Abbott, University of \\ California, Irvine, USA

\section{*Correspondence:} \\ Jean-Yves Tano and Maik Gollasch, \\ Experimental and Clinical Research \\ Center, Lindenberger Weg 80, \\ 13125 Berlin, Germany \\ e-mail: jean-yves.tano@charite.de; \\ maik.gollasch@charite.de
}

Ischemia and reperfusion (IR) injury constitutes one of the major causes of cardiovascular morbidity and mortality. The discovery of new therapies to block/mediate the effects of IR is therefore an important goal in the biomedical sciences. Dysfunction associated with IR involves modification of calcium-activated potassium channels $\left(\mathrm{K}_{\mathrm{Ca}}\right)$ through different mechanisms, which are still under study. Respectively, the $\mathrm{K}_{\mathrm{Ca}}$ family, major contributors to plasma membrane calcium influx in cells and essential players in the regulation of the vascular tone are interesting candidates. This family is divided into two groups including the large conductance $\left(\mathrm{BK}_{\mathrm{Ca}}\right)$ and the small/intermediate conductance $\left(\mathrm{SK}_{\mathrm{Ca}} / / \mathrm{K}_{\mathrm{Ca}}\right) \mathrm{K}^{+}$channels. In the heart and brain, these channels have been described to offer protection against IR injury. $\mathrm{BK}_{\mathrm{Ca}}$ and $\mathrm{SK}_{\mathrm{Ca}}$ channels deserve special attention since new data demonstrate that these channels are also expressed in mitochondria. More studies are however needed to fully determine their potential use as therapeutic targets.

Keywords: ischemia-reperfusion, $\mathrm{K}_{\mathrm{Ca}}$ channels, potassium channels, cardiovascular

\section{INTRODUCTION}

The proper function of the vasculature requires an intricate balance between plasma membrane ion channels embedded in the endothelium and smooth muscle cells (Luksha et al., 2009). In this regard, the calcium-activated potassium channels $\left(\mathrm{K}_{\mathrm{Ca}}\right)$ exert a great influence in this process (Brayden and Nelson, 1992; Félétou, 2009). These potassium channels possess high sensitivity to intracellular calcium as well as to changes in membrane voltage (Yang et al., 2012). Vascular dysfunction, which is a characteristic trait of several pathophysiological problems such as ischemia-reperfusion (IR) injury, is usually associated with a breakdown of mechanisms in the endothelium or smooth muscle cells. Many of these mechanisms involve the contribution of ion channels including the $\mathrm{K}_{\mathrm{Ca}}$. Due to their importance in the regulation of the vascular tone, the plasma membrane $\mathrm{K}_{\mathrm{Ca}}$ channels have been under scrutiny to resolve vascular dysfunction. Consequently, their role in IR injury has been uncovered with the use of pharmacological tools and more recently with animal models. Our objective in this mini-review is to highlight the observed beneficial effect of $\mathrm{K}_{\mathrm{Ca}}$ channels under IR conditions.

\section{STRUCTURE AND FUNCTION OF $\mathrm{K}_{\mathrm{Ca}}$ CHANNELS}

On the basis of structure, the $\mathrm{K}_{\mathrm{Ca}}$ family of potassium channels comprises two groups (Wei et al., 2005). Due to sequence similarity in the pore region and in the C-terminal bound calmodulin $\mathrm{Ca}^{2+}$ sensing domain, the small-conductance $\left(\mathrm{SK}_{\mathrm{Ca}} 1,2,3\right)$ and intermediate conductance $\left(\mathrm{IK}_{\mathrm{Ca}} 1\right)$ belong to the same subgroup (Wei et al., 2005). The large-conductance $\mathrm{BK}_{\mathrm{Ca}}$, Slo3, Slack, and Slick are also grouped together although Slo3, Slack, and Slick are insensitive to internal calcium (Wei et al., 2005) (see Table 1: for simplicity, only the $\mathrm{Ca}^{2+}$ activated potassium channels are shown). In contrast to the other members of the family, the $\mathrm{BK}_{\mathrm{Ca}}$ channels are unique in that they are not only calcium but also markedly voltage sensitive and that calcium binds directly at a specific domain within the protein structure (Wei et al., 1994; Schreiber and Salkoff, 1997). BK $\mathrm{Ca}$ channels can be in complex with several modulatory subunits (Figure 1) that greatly modify the channel kinetics and voltage/ $\mathrm{Ca}^{2+}$ sensitivities: $\beta 1-\beta 4$ have two transmembrane domains, while leucine-rich repeatcontaining proteins LRRC26, LRRC38, LRRC52, and LRRC55 are single pass membrane proteins with LRRC26 being the most potent activator producing a negative shift of approximately $140 \mathrm{mV}$ of the voltage dependence of activation (Yan and Aldrich, 2010, 2012; Singh et al., 2012). LRRC26 is a functional BK Channel auxiliary $\gamma$ subunit in arterial smooth muscle (Evanson et al., 2014). $\mathrm{SK}_{\mathrm{Ca}}$ and $\mathrm{IK}_{\mathrm{Ca}}$ channels, however, are very sensitive to changes in $\left[\mathrm{Ca}^{2+}\right]_{\mathrm{i}}$ (submicromolar), whose activation of the channels depends on the binding to a constitutively attached calmodulin (Burnham et al., 2002; Bychkov et al., 2002). SK $\mathrm{Ca}$ and $\mathrm{IK}_{\mathrm{Ca}}$ are expressed predominantly in the endothelial cells whereas $\mathrm{BK}_{\mathrm{Ca}}$ can be found in greater numbers in the smooth muscle cells (Yang et al., 2012). In the vasculature, these channels contribute predominantly in the regulation of the vascular tone.

$\mathrm{SK}_{\mathrm{Ca}}$ and $\mathrm{IK}_{\mathrm{Ca}}$ in the endothelium facilitate the endothelialderived hyperpolarizing factor mediated relaxation (EDHF) and more recently were found to be important for nitric oxide release (Doughty et al., 1999; McNeish et al., 2006; Stankevicius et al., 2006; Absi et al., 2007; Brähler et al., 2009). At least in mice, the EDHF response is caused by hydrogen peroxide, but not by cytochrome P450 eicosanoids (Hercule et al., 2009). In effect, 
Table 1 | Nomenclature of the calcium-activated potassium channels and their described participation in IR injury.

\begin{tabular}{llll}
\hline IUPHAR Name & Common name & HGNC & Role in IR injury \\
\hline $\mathrm{K}_{\mathrm{Ca}} 1.1$ & $\mathrm{Slo}, \mathrm{Slo1, \textrm {BK }}$ & $K C N M A 1$ & $\begin{array}{l}\text { Heart: Protection } \\
\text { Brain: Protection }\end{array}$ \\
\hline $\mathrm{K}_{\mathrm{Ca}} 2.1$ & $\mathrm{SK}_{\mathrm{Ca}}, \mathrm{SK}_{\mathrm{Ca}} 2$ & $K C N N 1$ & Heart: Protection \\
$\mathrm{K}_{\mathrm{Ca}} 2.2$ & & $K C N N 2$ & Brain: Protection \\
$\mathrm{K}_{\mathrm{Ca}} 2.3$ & & $K C N N 3$ & \\
\hline $\mathrm{K}_{\mathrm{Ca}} 3.1$ & $\mathrm{~K}_{\mathrm{Ca}}, \mathrm{K}_{\mathrm{Ca}} 1$ & $K C N N 4$ & Heart: Protection \\
& & & Brain: Protection
\end{tabular}

All of the channels seem to provide protection against injury in the heart and the brain whether administered pre- or post-ischemia. Abbreviations: IUPHAR, International Union of Pharmacology; HGNC, HUGO Gene Nomenclature Committee; IR, Ischemia-Reperfusion.

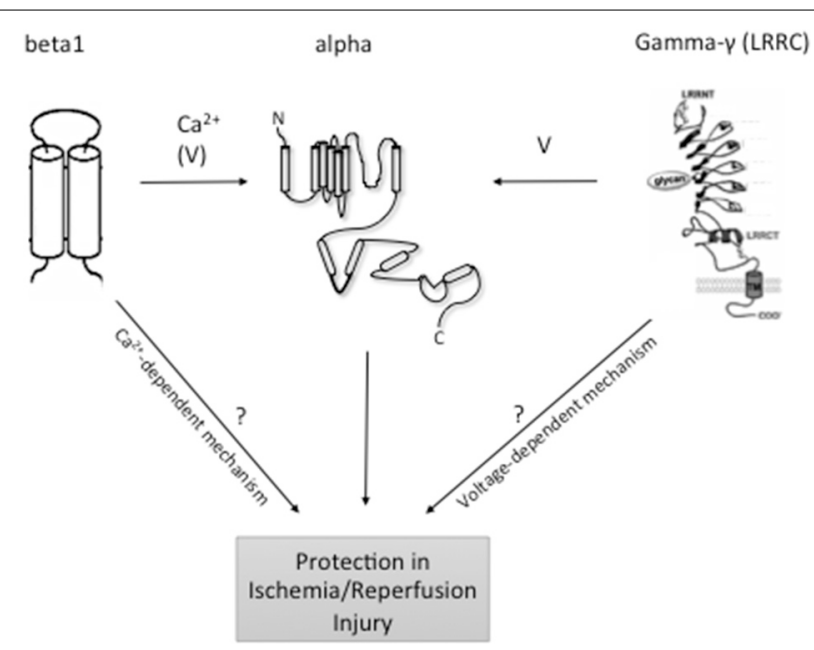

FIGURE 1 | Topology of $\mathbf{B K}_{\mathbf{C a}}$ and modulatory subunits. At the plasma membrane, the $\mathrm{N}$-terminus of $\mathrm{BK}_{\mathrm{Ca}} \alpha$-subunits is extracellular, and the C-terminus is intracellular. Orientation in organelles is unknown. S0-S4 transmembrane domains are involved in voltage sensing. The S5-S6 linker lines the $\mathrm{K}+$ selective pore. Four $\alpha$-subunits are needed to form a functional channel. $\beta 1-\beta 4$ subunits have two transmembrane domains. $\mathrm{N}$ - and C-termini are facing the same side of the membrane. $\gamma$ (LRRC)-subunits have a single transmembrane domain. $\mathrm{N}$ - and $\mathrm{C}$-termini face opposite sides of the membrane. $ß$ subunits have a major impact on the intracellular $\mathrm{Ca}^{2+}$ sensitivity of the channels, whereas $\gamma$ subunits have major effects on $\mathrm{BK}_{\mathrm{Ca}}$ channel voltage sensitivity to different degrees. Following reperfusion, an exacerbated accumulation of $\left[\mathrm{Ca}^{2+}\right]_{\mathrm{i}}$ mainly in the mitochondria, along with a significant increase in ROS and inflammation may result in cellular death. At least, mitoBK $\mathrm{Ca}_{\mathrm{a}}$ channels play a protective role against IR injury through thus far unclear mechanisms. LRRC exhibit tissue-specific expression although which individual cell types express LRRC proteins is unclear. Organ- and organelle-specific deletion of BK $\mathrm{Ca}$ LRRC and $ß$ subunits may clarify the role of $\left[\mathrm{Ca}^{2+}\right]_{i}$ accumulation vs. membrane potential in the protective effects of $\mathrm{BK}_{\mathrm{Ca}}$ channels in IR.

following an increase in $\left[\mathrm{Ca}^{2+}\right]_{\mathrm{i}}$ in endothelial cells, $\mathrm{SK}_{\mathrm{Ca}}$, and $\mathrm{IK}_{\mathrm{Ca}}$ channels open, causing membrane hyperpolarization. Local calcium $\left(\mathrm{Ca}^{2+}\right)$ signals ("sparklets") generated through cooperative opening of individual TRPV4 channels within a four-channel cluster can open plasma membrane $\mathrm{IK}_{\mathrm{Ca}}$ and $\mathrm{SK}_{\mathrm{Ca}}$ channels to cause vasodilation (Sonkusare et al., 2012). The hyperpolarization in turn leads to the electrical coupling of the endothelium and smooth muscle cells through myoendothelial gap junctions and vasorelaxation (Félétou, 2009). In parallel, opening of these channels can cause activation of the inward rectifier Kir2.1 channels and/or the $\mathrm{Na}^{+} / \mathrm{K}^{+}$ATPase on the smooth muscle cells, another important mechanism in the EDHF-mediated relaxation (Edwards et al., 1998). The coupling of the $\mathrm{SK}_{\mathrm{Ca}}$ and $\mathrm{IK}_{\mathrm{Ca}}$ channels activation to NO release is currently under study and involves several different mechanisms discussed extensively in Dalsgaard et al. (2010).

In arterial smooth muscle cells, $\mathrm{BK}_{\mathrm{Ca}}$ channels are involved in regulation of the vascular tone primarily through hyperpolarization and limitation of calcium influx through $\mathrm{Ca}_{\mathrm{v}} 1.2 \mathrm{~L}$-type $\mathrm{Ca}^{2+}$ channels (Brayden and Nelson, 1992; Sausbier et al., 2005; Yang et al., 2012). Calcium sparks generated by opening of ryanodine receptors (RyR) in the sarcoplasmic reticulum serve as local elementary $\mathrm{Ca}^{2+}$ signals to open plasma membrane $\mathrm{BK}_{\mathrm{Ca}}$ channels to induce membrane hyperpolarization and relaxation (Nelson et al., 1995; Gollasch et al., 1998; Essin et al., 2007), including in human vessels (Fürstenau et al., 2000). The accessory betal subunit of the $\mathrm{BK}_{\mathrm{Ca}}$ channel plays an important role in calcium spark/BK channel coupling (Brenner et al., 2000; Plüger et al., 2000). Calcium sparks are possibly generated by opening of RyR2 (Essin and Gollasch, 2009; Vaithianathan et al., 2010), but not by RyR3 (Löhn et al., 2001). In addition, $\mathrm{BK}_{\mathrm{Ca}}$ channels can contribute to endothelium-dependent vasorelaxation through activation by NO and EDHF (Bolotina et al., 1994; Weston et al., 2005; Hou et al., 2009). Interestingly, new studies have demonstrated the activation of $\mathrm{BK}$ channels by other gasotransmitters, notably carbon monoxide $(\mathrm{CO})$ and hydrogen sulfide $\left(\mathrm{H}_{2} \mathrm{~S}\right)$ (Dong et al., 2007; Chai et al., 2014) although see Telezhkin et al. (2010).

In view of their prominent role in the regulation of the vascular tone, the likelihood of involvement of these channels in IR-a condition where mechanisms underlying vasorelaxation are compromised and where gasotransmitters have been shown to play a protective role-is very high (Murphy and Steenbergen, 2008; Luksha et al., 2009; Dalsgaard et al., 2010; Eltzschig and Eckle, 2011). Recent studies have better defined the role of $\mathrm{BK}_{\mathrm{Ca}}$ in $\mathrm{IR}$, however the picture concerning $\mathrm{SK}_{\mathrm{Ca}}$ and $\mathrm{IK}_{\mathrm{Ca}}$ remains still cloudy.



A primary mechanism involved in IR injury is the exacerbation of intracellular calcium, which causes damages in the tissue (discussed in more detail in Eltzschig and Eckle (2011), Tano and Gollasch (2014). Limited studies have looked at the role of $\mathrm{SK}_{\mathrm{Ca}}$ and $\mathrm{IK}_{\mathrm{Ca}}$ in IR injury. Yang et al. recently demonstrated a decrease in endothelial $\mathrm{IK}_{\mathrm{Ca}}$ and $\mathrm{SK}_{\mathrm{Ca}}$ currents as well as $\mathrm{IK}_{\mathrm{Ca}}$ protein content, associated with a decreased EDHF-mediated relaxation following $60 \mathrm{~min}$ ischemia and $30 \mathrm{~min}$ reoxygenation in pig arteries (Yang et al., 2011). This study suggests that these channels are important in the protection of the endothelium against IR injury. A more recent and rigorous study looking at isolated guinea pig hearts also found protection against IR injury through SK $_{\mathrm{Ca}}$ channels (Stowe et al., 2006). In this study, DCEBIO, an 
$\mathrm{SK}_{\mathrm{Ca}}$, and $\mathrm{IK}_{\mathrm{Ca}}$ channel activator, caused a 2-fold increase in left ventricular pressure as well as a 2.5 fold decrease in infarct size when administered for $10 \mathrm{~min}, 20 \mathrm{~min}$ before IR. This effect is, however, blocked by NS8593, an $\mathrm{SK}_{\mathrm{Ca}}$ blocker, suggesting that these channels are responsible for the protection. Interestingly and most importantly, the authors isolate and purify novel $\mathrm{mSK}_{\mathrm{Ca}}$ channels from the inner mitochondrial membrane of cardiac cell and suggest that DCEBIO mediates its cardioprotection through these channels (Stowe et al., 2006), by improving mitochondrial bioenergetics (Stowe et al., 2013).

In the brain, a few studies have also demonstrated a protective role of $\mathrm{SK}_{\mathrm{Ca}}$ and a more ambiguous role for $\mathrm{IK}_{\mathrm{Ca}}$. In mice undergoing cardiac arrest/cardiopulmonary resuscitation (CA/CPR) and global cerebral ischemia, $\mathrm{SK}_{\mathrm{Ca}} 2$ channels are responsible for the protection of the CA1 neurons against ischemic injury (Allen et al., 2011). Similarly to the study in the heart, pre-stimulation of $\mathrm{SK}_{\mathrm{Ca}} 2$ with 1 -EBIO diminished significantly the adverse effects of CA/CPR, an effect, which could be reversed with administration of apamin (a specific $\mathrm{SK}_{\mathrm{Ca}}$ blocker). In addition, $\mathrm{SK}_{\mathrm{Ca}} 2$ electrophysiological activity was reduced during CA/CPR in association with an increased synaptic $\mathrm{SK}_{\mathrm{Ca}} 2$ channels internalization. Interestingly, post-treatment with 1 -EBIO was able to also blunt the effects of CA/CPR (Allen et al., 2011). In the parenchymal arterioles, both $\mathrm{SK}_{\mathrm{Ca}}$ and $\mathrm{IK}_{\mathrm{Ca}}$ were shown to play a protective role on the basal tone and pressure reactivity following IR (Cipolla et al., 2009). Blockade of these channels in the parenchymal arterioles induced a significant increase in the basal tone, which was preserved following IR injury when compared to control animals. Furthermore, the authors suggest that EDHF act as a substitute for $\mathrm{NO}$ in the parenchymal arterioles due to the fact that NO responsiveness is significantly decreased after IR (Cipolla et al., 2009). Finally, a recent study demonstrated that inhibition of IK $\mathrm{Ca}$ with the blocker TRAM-34 reduces infarct size and other neurological deficits in rats when administered as soon as $12 \mathrm{~h}$ after middle cerebral artery occlusion (Chen et al., 2011). The mechanism suggested for the protective actions of this drug is through the reduced activation of microglial cells, which is more noticeable with a higher dose $(40 \mathrm{mg} / \mathrm{Kg}$ ) of TRAM-34 (Chen et al., 2011).

Since the studies described in this review represent the only few published on this topic, one can see that much more work is required to properly decipher the role of these important channels in IR injury. It is especially difficult to understand the role of these channels since most of these studies take very different pharmacological approaches, notably pre-, and post-administration of inhibitors or blockers in conjunction with IR. Moreover, the use of available knockout mouse models of these channels would bring the scientific community closer to this goal. The prominent trend, however, seems to be a protective effect of these channels in the heart and the brain (see Table 1), which is also evident for $\mathrm{BK}_{\mathrm{Ca}}$ channels.

\section{BK $_{\text {Ca }}$ IN ISCHEMIA-REPERFUSION}

The combination of pharmacological tools and knockout mouse models has suggested a protective role of $\mathrm{BK}_{\mathrm{Ca}}$ against IR injury. The use of pharmacological activators such as NS1619 and NS11021 suggested $\mathrm{BK}_{\mathrm{Ca}}$ channels as cardioprotective following
IR (Shintani et al., 2004; Shi et al., 2007; Bentzen et al., 2009). This notion was recently confirmed with the use of the Kcnma1 knockout mouse where the cardioprotective effects of these channels were lost (Wojtovich et al., 2013). Furthermore, Woodman et al. determined the effects of tetraethylammonium (TEA, $1 \mathrm{mM}-$ a potent blocking concentration for $\mathrm{BK}_{\mathrm{Ca}}$ channels (see Nelson, 1993 ) to coronary arteries from dogs subjected to IR. TEA significantly shifted the concentration response curve of the ischemic vessels to acetylcholine to the right, though without decreasing the maximal relaxation (Chan and Woodman, 1999). The authors concluded that EDHF may be the factor responsible for activation of $\mathrm{BK}_{\mathrm{Ca}}$ channels (Chan and Woodman, 1999). However, the data have to be interpreted with caution since a number of other $\mathrm{K}+$ channels are sensitive to TEA, within this range of concentration, e.g., Kv1.1, Kv1.3, and Kv1.6 (Al-Sabi et al., 2013), KCNQ1, KCNQ2, KCNQ4, KCNQ2 + KCNQ3 (Hadley et al., 2000). In skeletal muscle arterioles from patients undergoing cardiopulmonary bypass, Feng et al. observed activation of the $\mathrm{BK}_{\mathrm{Ca}}$ channels (Feng et al., 2009). In addition, treatment with iberiotoxin (a specific $\mathrm{BK}_{\mathrm{Ca}}$ blocker) improved the myogenic tone significantly associated with a reduced microvessel internal diameter in these patients. The molecular mechanisms of the protective effects of $\mathrm{BK}_{\mathrm{Ca}}$ channels in IR may involve direct effects of hypoxia on $\mathrm{BK}_{\mathrm{Ca}}$ channel gating, without involvement of soluble intracellular components (Lewis et al., 2002). Sensitivity to hypoxia is conferred by a highly conserved motif within an alternatively spliced cysteine-rich insert, the stress-regulated exon (STREX), within the intracellular C-terminus of the channel (McCartney et al., 2005). Recent studies using Kcnmal knockout mice suggest that activation of cardiomyocyte $\mathrm{BK}_{\mathrm{Ca}}$ channels in mitochondria $\left(\right.$ mitoBK $_{\mathrm{Ca}}$ ) is one mechanism that protects the heart against IR injury (Singh et al., 2013; Tano and Gollasch, 2014). It is possible that sulfhydryl groups of the channel protein play a critical role in this process (Sitdikova et al., 2010; Liu et al., 2012).

The Kcnmal knockout mouse was also used to study $\mathrm{BK}_{\mathrm{Ca}}$ channels in the brain. These channels offered protection and reduced infarct size in a middle cerebral artery occlusion model (Liao et al., 2010). Interestingly, $\mathrm{Gu}$ et al. found that unlike healthy brain cells, glioma mitoBK $\mathrm{Ca}_{\mathrm{a}}$ channels, but not plasma membrane BK channels are oxygen sensitive (Gu et al., 2014). These findings may explain why tumor cells are resistant to hypoxia. On the other hand, discovery of this mechanism of tumor tolerance may have important clinical implications for the development of novel therapies in oncology.

\section{CONCLUSION}

The $\mathrm{K}_{\mathrm{Ca}}$ play an essential function in the endothelium and arterial smooth muscle where they participate actively in the regulation of the myogenic tone. Disruption of this process as well as others such as NO formation in IR injury provides a reason to study a potential involvement of these channels in IR. Thus far, the consensus points toward a protective role of these channels against IR injury, although much more remains unknown, notably the mechanisms underlying this protection. The use of gene knockout mouse models, especially for the $\mathrm{SK}_{\mathrm{Ca}}$, and $\mathrm{IK}_{\mathrm{Ca}}$ would be of great help in answering these questions. Also, the very recent discovery 
of $\mathrm{BK}_{\mathrm{Ca}}$ channel auxiliary $\gamma$ subunits, such as LRRC26, LRRC38, LRRC52, and LRRC55 (Yan and Aldrich, 2010, 2012), may help to design experimental protocols to clarify the role of excess calcium vs. plasma/mito membrane potential in the protective $\mathrm{BK}_{\mathrm{Ca}}$ function in IR injury (Figure 1). In this regard, targeting $\mathrm{BK}_{\mathrm{Ca}}$ $\beta$ subunits but not $\gamma$ subunits is expected to affect IR injury if excess calcium plays a key role in this process. Future studies are necessary to address the composition of functional $\mathrm{BK}_{\mathrm{Ca}}$ channels in the organs and organelles of interest (mitochondria) and to study their role in IR using genetically engineered $\mathrm{BK}_{\mathrm{Ca}}$ subunit deficient animal models.

\section{ACKNOWLEDGMENTS}

The Deutsche Forschungsgemeinschaft (DFG) and the Alexander von Humboldt foundation support the work of the authors.

\section{REFERENCES}

Absi, M., Burnham, M. P., Weston, A. H., Harno, E., Rogers, M., and Edwards, G. (2007). Effects of methyl beta-cyclodextrin on EDHF responses in pig and rat arteries; association between $\mathrm{SK}(\mathrm{Ca})$ channels and caveolin-rich domains. Br. J. Pharmacol. 151, 332-340. doi: 10.1038/sj.bjp.0707222

Allen, D., Nakayama, S., Kuroiwa, M., Nakano, T., Palmateer, J., Kosaka, Y., et al. (2011). SK2 channels are neuroprotective for ischemia-induced neuronal cell death. J. Cereb. Blood Flow Metab. 31, 2302-2312. doi: 10.1038/jcbfm. 2011.90

Al-Sabi, A., Kaza, S. K., Dolly, J. O., and Wang, J. (2013). Pharmacological characteristics of Kv1.1- and Kv1.2-containing channels are influenced by the stoichiometry and positioning of their $\alpha$ subunits. Biochem. J. 454, 101-108. doi: 10.1042/BJ20130297

Bentzen, B. H., Osadchii, O., Jespersen, T., Hansen, R. S., Olesen, S.-P., and Grunnet, M. (2009). Activation of big conductance $\mathrm{Ca}(2+)$-activated $\mathrm{K}(+)$ channels $(\mathrm{BK})$ protects the heart against ischemia-reperfusion injury. Pflugers Arch. 457, 979-988. doi: 10.1007/s00424-008-0583-5

Bolotina, V. M., Najibi, S., Palacino, J. J., Pagano, P. J., and Cohen, R. A. (1994). Nitric oxide directly activates calcium-dependent potassium channels in vascular smooth muscle. Nature 368, 850-853. doi: 10.1038/368850a0

Brähler, S., Kaistha, A., Schmidt, V. J., Wölfle, S. E., Busch, C., Kaistha, B. P., et al. (2009). Genetic deficit of SK3 and IK1 channels disrupts the endotheliumderived hyperpolarizing factor vasodilator pathway and causes hypertension. Circulation 119, 2323-2332. doi: 10.1161/CIRCULATIONAHA.108.846634

Brayden, J. E., and Nelson, M. T. (1992). Regulation of arterial tone by activation of calcium-dependent potassium channels. Science 256, 532-535. doi: 10.1126/science.1373909

Brenner, R., Peréz, G. J., Bonev, A. D., Eckman, D. M., Kosek, J. C., Wiler, S. W., et al. (2000). Vasoregulation by the betal subunit of the calcium-activated potassium channel. Nature 407, 870-876. doi: 10.1038/35038011

Burnham, M. P., Bychkov, R., Félétou, M., Richards, G. R., Vanhoutte, P. M., Weston, A. H., et al. (2002). Characterization of an apamin-sensitive small-conductance $\mathrm{Ca}(2+)$-activated $\mathrm{K}(+)$ channel in porcine coronary artery endothelium: relevance to EDHF. Br. J. Pharmacol. 135, 1133-1143. doi: 10.1038/sj.bjp.0704551

Bychkov, R., Burnham, M. P., Richards, G. R., Edwards, G., Weston, A. H., Félétou, M., et al. (2002). Characterization of a charybdotoxin-sensitive intermediate conductance $\mathrm{Ca} 2+$-activated $\mathrm{K}+$ channel in porcine coronary endothelium: relevance to EDHF. Br. J. Pharmacol. 137, 1346-1354. doi: 10.1038/sj.bjp.0705057

Chai, Q., Lu, T., Wang, X. L., and Lee, H. C. (2014). Hydrogen sulfide impairs shear stress-induced vasodilation in mouse coronary arteries. Pflügers Arch. doi: 10. 1007/s00424-014-1526-y. [Epub ahead of print].

Chan, E. C., and Woodman, O. L. (1999). Enhanced role for the opening of potassium channels in relaxant responses to acetylcholine after myocardial ischaemia and reperfusion in dog coronary arteries. Br. J. Pharmacol. 126, 925-932. doi: 10.1038/sj.bjp.0702376

Chen, Y.-J., Raman, G., Bodendiek, S., O’Donnell, M. E., and Wulff, H. (2011). The KCa3.1 blocker TRAM-34 reduces infarction and neurological deficit in a rat model of ischemia/reperfusion stroke. J. Cereb. Blood Flow Metab. 31, 2363-2374. doi: 10.1038/jcbfm.2011.101
Cipolla, M. J., Smith, J., Kohlmeyer, M. M., and Godfrey, J. A. (2009). SKCa and IKCa Channels, myogenic tone, and vasodilator responses in middle cerebral arteries and parenchymal arterioles: effect of ischemia and reperfusion. Stroke 40, 1451-1457. doi: 10.1161/STROKEAHA.108.535435

Dalsgaard, T., Kroigaard, C., and Simonsen, U. (2010). Calcium-activated potassium channels - a therapeutic target for modulating nitric oxide in cardiovascular disease? Expert Opin. Ther. Targets 14, 825-837. doi: $10.1517 / 14728222.2010 .500616$

Dong, D.-L., Zhang, Y., Lin, D.-H., Chen, J., Patschan, S., Goligorsky, M. S., et al. (2007). Carbon monoxide stimulates the $\mathrm{Ca}^{2+}$-activated big conductance $\mathrm{K}$ channels in cultured human endothelial cells. Hypertension 50, 643-651. doi: 10.1161/HYPERTENSIONAHA.107.096057

Doughty, J. M., Plane, F., and Langton, P. D. (1999). Charybdotoxin and apamin block EDHF in rat mesenteric artery if selectively applied to the endothelium. Am. J. Physiol. 276, H1107-H1112.

Edwards, G., Dora, K. A., Gardener, M. J., Garland, C. J., and Weston, A. H. (1998). $\mathrm{K}+$ is an endothelium-derived hyperpolarizing factor in rat arteries. Nature 396, 269-272. doi: 10.1038/24388

Eltzschig, H. K., and Eckle, T. (2011). Ischemia and reperfusion-from mechanism to translation. Nat. Med. 17, 1391-1401. doi: 10.1038/nm.2507

Essin, K., and Gollasch, M. (2009). Role of ryanodine receptor subtypes in initiation and formation of calcium sparks in arterial smooth muscle: comparison with striated muscle. J. Biomed. Biotechnol. 2009:135249. doi: 10.1155/2009/ 135249

Essin, K., Welling, A., Hofmann, F., Luft, F. C., Gollasch, M., and Moosmang, S. (2007). Indirect coupling between Cav1.2 channels and ryanodine receptors to generate $\mathrm{Ca} 2+$ sparks in murine arterial smooth muscle cells. J. Physiol. 584, 205-219. doi: 10.1113/jphysiol.2007.138982

Evanson, K. W., Bannister, J. P., Leo, M. D., and Jaggar, J. H. (2014). LRRC26 is a functional BK channel auxiliary $\gamma$ subunit in arterial smooth muscle cells. Circ. Res. 115, 423-431. doi: 10.1161/CIRCRESAHA.115.303407

Félétou, M. (2009). Calcium-activated potassium channels and endothelial dysfunction: therapeutic options? Br. J. Pharmacol. 156, 545-562. doi: 10.1111/j.1476-5381.2009.00052.x

Feng, J., Liu, Y., Khabbaz, K. R., Sodha, N. R., Osipov, R. M., Hagberg, R., et al. (2009). Large conductance calcium-activated potassium channels contribute to the reduced myogenic tone of peripheral microvasculature after cardiopulmonary bypass1. J. Surg. Res. 157, 123-128. doi: 10.1016/j.jss.2009.03.043

Fürstenau, M., Löhn, M., Ried, C., Luft, F. C., Haller, H., and Gollasch, M. (2000). Calcium sparks in human coronary artery smooth muscle cells resolved by confocal imaging. J. Hypertens. 18, 1215-1222. doi: 10.1097/00004872-20001809000007

Gollasch, M., Wellman, G. C., Knot, H. J., Jaggar, J. H., Damon, D. H., Bonev, A. D., et al. (1998). Ontogeny of local sarcoplasmic reticulum $\mathrm{Ca} 2+$ signals in cerebral arteries: Ca2+ sparks as elementary physiological events. Circ. Res. 83, 1104-1114. doi: 10.1161/01.RES.83.11.1104

Gu, X. Q., Pamenter, M. E., Siemen, D., Sun, X., and Haddad, G. G. (2014). Mitochondrial but not plasmalemmal BK channels are hypoxia-sensitive in human glioma. Glia 62, 504-513. doi: 10.1002/glia.22620

Hadley, J. K., Noda, M., Selyanko, A. A., Wood, I. C., Abogadie, F. C., and Brown, D. A. (2000). Differential tetraethylammonium sensitivity of KCNQ1-4 potassium channels. Br. J. Pharmacol. 129, 413-415. doi: 10.1038/sj.bjp.0703086

Hercule, H. C., Schunck, W.-H., Gross, V., Seringer, J., Leung, F. P., Weldon, S. M., et al. (2009). Interaction between P450 eicosanoids and nitric oxide in the control of arterial tone in mice. Arterioscler. Thromb. Vasc. Biol. 29, 54-60. doi: 10.1161/ATVBAHA.108.171298

Hou, S., Heinemann, S. H., and Hoshi, T. (2009). Modulation of BKCa channel gating by endogenous signaling molecules. Physiology (Bethesda) 24, 26-35. doi: 10.1152/physiol.00032.2008

Lewis, A., Peers, C., Ashford, M. L. J., and Kemp, P. J. (2002). Hypoxia inhibits human recombinant large conductance, $\mathrm{Ca}(2+)$-activated $\mathrm{K}(+)$ (maxi-K) channels by a mechanism which is membrane delimited and $\mathrm{Ca}(2+)$ sensitive. J. Physiol. 540, 771-780. doi: 10.1113/jphysiol.2001.013888

Liao, Y., Kristiansen, A.-M., Oksvold, C. P., Tuvnes, F. A., Gu, N., Rundén-Pran, E., et al. (2010). Neuronal Ca2+-activated $\mathrm{K}+$ channels limit brain infarction and promote survival. PLoS ONE 5:e15601. doi: 10.1371/journal.pone.0015601

Liu, Y., Kalogeris, T., Wang, M., Zuidema, M. Y., Wang, Q., Dai, H., et al. (2012). Hydrogen sulfide preconditioning or neutrophil depletion attenuates ischemia-reperfusion-induced mitochondrial dysfunction in rat small 
intestine. Am. J. Physiol. Gastrointest. Liver Physiol. 302, G44-G54. doi: 10.1152/ajpgi.00413.2010

Löhn, M., Jessner, W., Fürstenau, M., Wellner, M., Sorrentino, V., Haller, H., et al. (2001). Regulation of calcium sparks and spontaneous transient outward currents by RyR3 in arterial vascular smooth muscle cells. Circ. Res. 89, 1051-1057. doi: 10.1161/hh2301.100250

Luksha, L., Agewall, S., and Kublickiene, K. (2009). Endothelium-derived hyperpolarizing factor in vascular physiology and cardiovascular disease. Atherosclerosis 202, 330-344. doi: 10.1016/j.atherosclerosis.2008.06.008

McCartney, C. E., McClafferty, H., Huibant, J.-M., Rowan, E. G., Shipston, M. J., and Rowe, I. C. M. (2005). A cysteine-rich motif confers hypoxia sensitivity to mammalian large conductance voltage- and Ca-activated $\mathrm{K}$ (BK) channel alpha-subunits. Proc. Natl. Acad. Sci. U.S.A. 102, 17870-17876. doi: 10.1073/pnas.0505270102

McNeish, A. J., Sandow, S. L., Neylon, C. B., Chen, M. X., Dora, K. A., and Garland, C. J. (2006). Evidence for involvement of both IKCa and SKCa channels in hyperpolarizing responses of the rat middle cerebral artery. Stroke 37, 1277-1282. doi: 10.1161/01.STR.0000217307.71231.43

Murphy, E., and Steenbergen, C. (2008). Mechanisms underlying acute protection from cardiac ischemia-reperfusion injury. Physiol. Rev. 88, 581-609. doi: 10.1152/physrev.00024.2007

Nelson, M. T. (1993). Ca(2+)-activated potassium channels and ATP-sensitive potassium channels as modulators of vascular tone. Trends Cardiovasc. Med. 3, 54-60. doi: 10.1016/1050-1738(93)90037-7

Nelson, M. T., Cheng, H., Rubart, M., Santana, L. F., Bonev, A. D., Knot, H. J., et al. (1995). Relaxation of arterial smooth muscle by calcium sparks. Science 270, 633-637. doi: 10.1126/science.270.5236.633

Plüger, S., Faulhaber, J., Fürstenau, M., Löhn, M., Waldschütz, R., Gollasch, M., et al. (2000). Mice with disrupted BK channel betal subunit gene feature abnormal $\mathrm{Ca}(2+)$ spark/STOC coupling and elevated blood pressure. Circ. Res. 87, E53-E60. doi: 10.1161/01.RES.87.11.e53

Sausbier, M., Arntz, C., Bucurenciu, I., Zhao, H., Zhou, X.-B., Sausbier, U., et al. (2005). Elevated blood pressure linked to primary hyperaldosteronism and impaired vasodilation in BK channel-deficient mice. Circulation 112, 60-68. doi: 10.1161/01.CIR.0000156448.74296.FE

Schreiber, M., and Salkoff, L. (1997). A novel calcium-sensing domain in the BK channel. Biophys. J. 73, 1355-1363. doi: 10.1016/S0006-3495(97)78168-2

Shi, Y., Jiang, M. T., Su, J., Hutchins, W., Konorev, E., and Baker, J. E. (2007). Mitochondrial big conductance KCa channel and cardioprotection in infant rabbit heart. J. Cardiovasc. Pharmacol. 50, 497-502. doi: 10.1097/FJC.0b013e318137991d

Shintani, Y., Node, K., Asanuma, H., Sanada, S., Takashima, S., Asano, Y., et al. (2004). Opening of Ca2+-activated $\mathrm{K}+$ channels is involved in ischemic preconditioning in canine hearts. J. Mol. Cell. Cardiol. 37, 1213-1218. doi: 10.1016/j.yjmcc.2004.09.012

Singh, H., Lu, R., Bopassa, J. C., Meredith, A. L., Stefani, E., and Toro, L. (2013). $\operatorname{MitoBK}(\mathrm{Ca})$ is encoded by the Kcnmal gene, and a splicing sequence defines its mitochondrial location. Proc. Natl. Acad. Sci. U.S.A. 110, 10836-10841. doi: $10.1073 /$ pnas. 1302028110

Singh, H., Stefani, E., and Toro, L. (2012). Intracellular BK(Ca) (iBK(Ca)) channels. J. Physiol. 590, 5937-5947. doi: 10.1113/jphysiol.2011.215533

Sitdikova, G. F., Weiger, T. M., and Hermann, A. (2010). Hydrogen sulfide increases calcium-activated potassium (BK) channel activity of rat pituitary tumor cells. Pflugers Arch. 459, 389-397. doi: 10.1007/s00424-009-0737-0

Sonkusare, S. K., Bonev, A. D., Ledoux, J., Liedtke, W., Kotlikoff, M. I., Heppner, T. J., et al. (2012). Elementary Ca2 + signals through endothelial TRPV4 channels regulate vascular function. Science 336, 597-601. doi: 10.1126/science.1216283

Stankevicius, E., Lopez-Valverde, V., Rivera, L., Hughes, A., Mulvany, M. J., and Simonsen, U. (2006). Combination of $\mathrm{Ca} 2+$-activated $\mathrm{K}+$ channel blockers inhibits acetylcholine-evoked nitric oxide release in rat superior mesenteric artery. Br. J. Pharmacol. 149, 560-572. doi: 10.1038/sj.bjp.0706886

Stowe, D. F., Aldakkak, M., Camara, A. K. S., Riess, M. L., Heinen, A., Varadarajan, S. G., et al. (2006). Cardiac mitochondrial preconditioning by Big Ca2+- sensitive $\mathrm{K}+$ channel opening requires superoxide radical generation. Am. J. Physiol. Heart Circ. Physiol. 290, H434-H440. doi: 10.1152/ajpheart.00763.2005

Stowe, D. F., Gadicherla, A. K., Zhou, Y., Aldakkak, M., Cheng, Q., Kwok, W.M., et al. (2013). Protection against cardiac injury by small $\mathrm{Ca}(2+)$-sensitive $\mathrm{K}(+)$ channels identified in guinea pig cardiac inner mitochondrial membrane. Biochim. Biophys. Acta 1828, 427-442. doi: 10.1016/j.bbamem.2012.08.031

Tano, J.-Y., and Gollasch, M. (2014). Hypoxia and ischemia-reperfusion: a BiK contribution? Am. J. Physiol. Heart Circ. Physiol. 307, H811-H817. doi: 10.1152/ajpheart.00319.2014

Telezhkin, V., Brazier, S. P., Cayzac, S. H., Wilkinson, W. J., Riccardi, D., and Kemp, P. J. (2010). Mechanism of inhibition by hydrogen sulfide of native and recombinant BKCa channels. Respir. Physiol. Neurobiol. 172, 169-178. doi: 10.1016/j.resp.2010.05.016

Vaithianathan, T., Narayanan, D., Asuncion-Chin, M. T., Jeyakumar, L. H., Liu, J., Fleischer, S., et al. (2010). Subtype identification and functional characterization of ryanodine receptors in rat cerebral artery myocytes. Am. J. Physiol. Cell Physiol. 299, C264-C278. doi: 10.1152/ajpcell.00318.2009

Wei, A. D., Gutman, G. A., Aldrich, R., Chandy, K. G., Grissmer, S., and Wulff, H. (2005). International Union of Pharmacology. LII. Nomenclature and molecular relationships of calcium-activated potassium channels. Pharmacol. Rev. 57, 463-472. doi: 10.1124/pr.57.4.9

Wei, A., Solaro, C., Lingle, C., and Salkoff, L. (1994). Calcium sensitivity of BKtype KCa channels determined by a separable domain. Neuron 13, 671-681. doi: 10.1016/0896-6273(94)90034-5

Weston, A. H., Félétou, M., Vanhoutte, P. M., Falck, J. R., Campbell, W. B., and Edwards, G. (2005). Bradykinin-induced, endothelium-dependent responses in porcine coronary arteries: involvement of potassium channel activation and epoxyeicosatrienoic acids. Br. J. Pharmacol. 145, 775-784. doi: 10.1038/sj.bjp.0706256

Wojtovich, A. P., Nadtochiy, S. M., Urciuoli, W. R., Smith, C. O., Grunnet, M., Nehrke, K., et al. (2013). A non-cardiomyocyte autonomous mechanism of cardioprotection involving the SLO1 BK channel. PeerJ 1:e48. doi: 10.7717/peerj.48 Yan, J., and Aldrich, R. W. (2010). LRRC26 auxiliary protein allows BK channel activation at resting voltage without calcium. Nature 466, 513-516. doi: 10.1038/nature09162

Yan, J., and Aldrich, R. W. (2012). BK potassium channel modulation by leucinerich repeat-containing proteins. Proc. Natl. Acad. Sci. U.S.A. 109, 7917-7922. doi: 10.1073/pnas.1205435109

Yang, Q., Huang, J.-H., Man, Y.-B., Yao, X.-Q., and He, G.-W. (2011). Use of intermediate/small conductance calcium-activated potassium-channel activator for endothelial protection. J. Thorac. Cardiovasc. Surg. 141, 501-510, 510.e1. doi: 10.1016/j.jtcvs.2010.04.005

Yang, Q., Underwood, M. J., and He, G.-W. (2012). Calcium-activated potassium channels in vasculature in response to ischemia-reperfusion. J. Cardiovasc. Pharmacol. 59, 109-115. doi: 10.1097/FJC.0b013e318210fb4b

Conflict of Interest Statement: The authors declare that the research was conducted in the absence of any commercial or financial relationships that could be construed as a potential conflict of interest.

Received: 14 July 2014; accepted: 13 September 2014; published online: 06 October 2014.

Citation: Tano J-Y and Gollasch M (2014) Calcium-activated potassium channels in ischemia reperfusion: a brief update. Front. Physiol. 5:381. doi: 10.3389/fphys. 2014.00381

This article was submitted to Membrane Physiology and Membrane Biophysics, a section of the journal Frontiers in Physiology.

Copyright (c) 2014 Tano and Gollasch. This is an open-access article distributed under the terms of the Creative Commons Attribution License (CC BY). The use, distribution or reproduction in other forums is permitted, provided the original author(s) or licensor are credited and that the original publication in this journal is cited, in accordance with accepted academic practice. No use, distribution or reproduction is permitted which does not comply with these terms. 